\title{
Cunninghame Graham
}

\author{
La ascendencia española de este \\ gran escritor inglés. Sus trabajos \\ sobre la historia de Hispano-Amé- \\ rica. "Donde los españoles fueron, \\ el indio lleva calzones..." Inglate- \\ rra, por medio de sus Almirantes, \\ maniobró contra la integridad de la \\ Gran Colombia.
}

Mi querido Lenc:

En su muy interesante nota sobre Cunninghame Graham publicada en El Tiempo, edición del 21 de marzo, olvidó usted un detalle muy importante, o sea la ascendencia española, por parte de madre, de este gran escritor inglés.

Dice usted que era muy inglés, pero con algo o mucho del alma latina. Pues esto se explica por este dato que paso a usted.

Va de cuento: Fué abuelo materno de Mr. Graham, el Almirante de la Escuadra Inglesa Charles Elphinstone Fleeming, casado con doña Catalina Paulina de Fleeming, hermosa dama española.

En 1828 el Almirante estaba en comando de la Escuadra Inglesa estacionada en las Antillas y su flagship era H. M. Barham. Destinado a Caracas en comisión semi-política, ocurrió que al llegar a la Guayra, su esposa, que lo acompañaba a bordo del buque, dió a luz una niña, que vino a ser la madre de Cunninghame Graham, ei "Don Quijote" inglés.

Apenas pudo la esposa del Almirante Fleeming montar una mula - entonces el único medio de transporte en esas montañas- 
se dirigió con su esposo y la pequeña niña a Caracas. Allá vivieron en una antigua casa española, muy cercana a la Catedral de esa ciudad.

El Almirante, que iba y venía en viajes por las Antillas, pasaba buenos días en Caracas y así vino a ser gran amigo del General Páez, entonces Jefe Supremo de Venezuela. Hay hasta la posibilidad de que tomase gran parte en la separación de Venezuela de Colombia, por aquello de que las potencias mayores siempre tienden a recortar, desmembrar o reducir cuanto pueda llegar a ser fuerza o factor de alguna significación en los futuros juegos de la política.

En honor de este Almirante, dió Páez una suntuosa comida en su histórica mansión La Viñeta. Allí se entonó una canción compuesta para tal ocasión. El coro decía así:

\author{
Venid, hijos ilustres \\ De Vespucio y Colón, \\ A conocer a Fleeming \\ Honor de su nación.
}

Esta abuela españolísima de Graham y la madre suya nacida en suelo hispanoamericano, explican, pues, ampliamente, la muy marcada simpatía del escritor inglés por las cosas españolas y muy especialmente de Hispanoamérica. ; Lo llevaba en la sangre!

Ignoro si en Colombia conocen el libro de Graham sobre el General Páez, publicado en 1932, por Macrae Emith and Company de Filadelfia y dedicado a Juan Eaton Kent, de San Fernando de Apure.

Tal obra está calcada sobre la autobiografía de Páez, pero con notas muy interesantes de Graham, y para escribirla y empaparse bien del asunto, vivió en los llanos de Venezuela por varios años. No he visto un solo comentario de la prensa colombiana sobre tan interesante obra, lo que me hace creer que allá es ignorada.

También quiero referirme aquí a otras varias obras de Graham sobre asuntos nuestros: The Conquest of the River Plata; A Brazilian Mystic; Cartagena and the Banks of Sinu River; Hernando de Soto; Pedro de Valdivia; A Vanished Arcadia; y The Conquest of New Granada.

Esta última obra se publicó en Boston en 1922 por Houghton Mifflin Company y está dedicada "A don Guillermo Valencia, excelso poeta, orador armonioso e irresistible, honra de las letras españolas en América”. (La dedicatoria está en español.) 
Desgraciadamente esta obra tiene muy poco de original. Toda ella es casi una traducción del Compendio Histórico del Descubrimiento y Colonización de la Nueva Granada, por el Coronel Joaquín Acosta. Yo he tenido la paciencia de cotejar algunos capítulos y resultan una traducción literal, en veces hasta descuidada, de la obra de nuestro compatriota. Naturalmente, ella tiene el mérito de que ayuda a divulgar nuestra historia entre las gentes de habla inglesa, y en gracia a esto, en alguna ocasión me opuse con éxito completo a la crítica que quería hacer a Graham por dicha razón, un muy conocido escritor de este país, a quien yo descubrí el plagio.

Graham, como dice usted, fué un gran amigo de Pérez Triana. Cuando éste murió, recuerdo que el escritor inglés dijo que la mejor música de cámara que había oído en Londres era en los recibos de Gran Señor que acostumbraba dar nuestro compatriota.

Una frase de Graham, muy famosa, que no hay que olvidar y que vale por todo un volumen, la dijo en respuesta a las acusaciones de crueldad que los de habla inglesa hacen a los españoles en sus relaciones con los indios: "No hay que olvidar que a donde los españoles fueron el indio lleva calzones..."

En efecto, el indio en este país fué expoliado, aniquilado por los colonos sajones, de cuya crueldad nadie habla. Los que aún quedan, como una curiosidad, viven en las reservations y llevan plumas. En la India, después de cientos de años de dominación inglesa, los indostanes viven al margen de la civilización moderna. Allá, como dijo el gran poeta Rabindranath Tagore, en una conferencia que hace años tuve la fortuna de oírle en la Universidad de Harvard, el inglés apenas ha arañado el suelo con sus ferrocarriles, malecones, e implementos agrícolas, pero no ha tocado el corazón del pueblo... Este milagro, debemos decir nosotros, sólo lo ha realizado la raza española, que a donde fué ha dado a las gentes cuanto tiene de suyo, bueno o malo, y los ha hecho parte integrante de su mundo.

Graham, inglés en su porte, era ciertamente original, romántico y en más de una vez requirió la tizona para defender a los pueblos de habla española. En su obra sobre Páez, al referirse a los proyectos de Bolívar para libertar a Cuba, dice que el ejército de Venezuela y Nueva Granada era en aquel tiempo, en todo el Continente americano, la mejor fuerza combatiente bajo las armas. Esto explica que Inglaterra ocultamente intrigara para disgregar el bloque grancolombiano y enviar a esas misiones confidenciales a su Almirante. 
Por lo demás, el nombre Fleeming tiene buenos ribetes de nombre irlandés; por esta razón Graham y Bernard Shaw, irlandés legítimo, se dan las manos en las travesuras de su pluma y de su itıgenio!

Enrique Naranjo Martínez, Boston, Massachusetts. 